ALCHEMY Jurnal Penelitian Kimia

Laman resmi: https://jurnal.uns.ac.id/alchemy

\title{
Karakterisasi dan Uji Efektivitas Allophane-Like untuk Adsorpsi Ion Logam Tembaga $(\mathrm{Cu})$
}

\author{
Pranoto Pranoto*, Tri Martini, Deta Agustin Rachmawati \\ Program Studi Kimia, Fakultas Matematika dan Ilmu Pengetahuan Alam, Universitas Sebelas Maret, Jl. Ir. \\ Sutami 36 A, Kentingan Surakarta 57126 telp. (0271) 663375 \\ *Corresponding author \\ E-mail: pakpranotomipa@staff.uns.ac.id \\ DOI: 10.20961/alchemy.14.2.18538.202-218
}

Received 07 February 2018, Accepted 23 March 2018, Published Online 03 September 2018

\begin{abstract}
ABSTRAK
Telah dilakukan penelitian karakterisasi dan uji efektivitas allophane-like untuk adsorpsi ion logam tembaga $(\mathrm{Cu})$. Allophane-like dibuat dengan mencampurkan larutan Tetraethyl Orthosilicate (TEOS) dan Aluminum Nitrate Nonahydrate $\left[\mathrm{Al}\left(\mathrm{NO}_{3}\right)_{3} .9 \mathrm{H}_{2} \mathrm{O}\right]$ dengan perbandingan 0,$5 ; 0,75 ; 1 ; 1,25$ dan 1 ,5. Proses pencampuran dilakukan penambahan $\mathrm{NaOH}$ secara bertahap dan dilakukan pengadukan serta pemanasan. Penambahan $\mathrm{NaOH}$ dilakukan dengan membuat perbandingan $\mathrm{NaOH}$ dan Campuran TEOS dan $\mathrm{Al}\left(\mathrm{NO}_{3}\right)_{3} .9 \mathrm{H}_{2} \mathrm{O} 3: 1$. $\mathrm{pH}$ campuran larutan yang diperoleh diukur dan $\mathrm{pH}$ larutan dibuat menjadi asam ( $\mathrm{pH} 3-$ 4). Allophane-like dikarakterisasi dengan spektroskopi infra merah (FTIR), XRD, keasaman, dan luas permukaan. Uji adsorpsi terhadap ion logam tembaga $(\mathrm{Cu})$ dilakukan pada variasi perbandingan TEOS dan $\mathrm{Al}\left(\mathrm{NO}_{3}\right)_{3} .9 \mathrm{H}_{2} \mathrm{O} 0,5 ; 0,75 ; 1 ; 1,25$ dan $1,5, \mathrm{pH}$ larutan tembaga $(\mathrm{Cu}) 3-7$ serta waktu kontak 30-120 menit dengan sistem batch. Hasil penelitian diketahui bahwa allophane-like memiliki gugus fungsi yang sama dengan allophane-alam yang ditunjukkan dengan data FTIR yaitu memiliki puncak yang sama pada 34313252; 1631; 1071; 785; dan 562-457 $\mathrm{cm}^{-1}$. Hasil analisa XRD, keasaman dan luas permukaan menunjukkan karakteristik yang berbeda. Kondisi adsorpsi ion logam tembaga $(\mathrm{Cu})$ terjadi pada variasi perbandingan TEOS dan $\mathrm{Al}\left(\mathrm{NO}_{3}\right)_{3} .9 \mathrm{H}_{2} \mathrm{O}$ 1,5, pH 6, waktu kontak 120 menit, persentase penyerapan 41,79\% dan kapasitas adsorpsi $0,97865 \mathrm{mg} / \mathrm{g}$.
\end{abstract}

Kata kunci : adsorpsi, allophane-like, ion logam tembaga $(\mathrm{Cu})$.

\begin{abstract}
Characterization and Effectivity of Allophane-Like in the Adsorption of Metal Ion of Copper (Cu). The characterization and effectivity testing of allophane-like for adsorption copper $(\mathrm{Cu})$ metal ion has been studied. Allophane-like was prepared by mixing a solution of Tetraethylorthosilicate (TEOS) and Aluminum Nitrate nonahydrate $\left[\mathrm{Al}\left(\mathrm{NO}_{3}\right)_{3} .9 \mathrm{H} 2 \mathrm{O}\right]$ using ratio of $0.5 ; 0.75 ; 1 ; 1.25$ and 1.5 . The mixing process was done gradually adding $\mathrm{NaOH}$ and stirring and heating. The addition of $\mathrm{NaOH}$ was done by making a comparison between $\mathrm{NaOH}$ and mixture of TEOS dan $\mathrm{Al}\left(\mathrm{NO}_{3}\right)_{3} .9 \mathrm{H}_{2} \mathrm{O}$ in 3:1. The $\mathrm{pH}$ of the mixture solution was measured and made acidic solution ( $\mathrm{pH} 3-4)$. Allophane-like was characterized by infrared spectroscopy (FTIR), XRD, acidity, and surface area. The adsorption evaluation of copper $(\mathrm{Cu})$ metal ion was done on the variation of the composition of TEOS dan $\mathrm{Al}\left(\mathrm{NO}_{3}\right)_{3} .9 \mathrm{H}_{2} \mathrm{O}$ in $0.5 ; 0.75 ; 1 ; 1.25$ and 1.5 , the $\mathrm{pH}$ of a solution of copper $(\mathrm{Cu}) 3-7$ and contact time of 30-120 minutes in batch system. The results revealed that the allophane-like has the same functional group with nature allophane indicated by the FTIR data that has the same peak at 3431-3252; 1631; 1071; 785; and 562-457 $\mathrm{cm}^{-1}$. XRD analysis results, acidity and surface area showed different characteristics. The best conditions adsorption of copper $(\mathrm{Cu})$ metal ion
\end{abstract}


occured at the composition of TEOS dan $\mathrm{Al}\left(\mathrm{NO}_{3}\right)_{3} \cdot 9 \mathrm{H}_{2} \mathrm{O}$ in $1.5, \mathrm{pH}$ 6, the contact time of 120 minutes, the absorption percentage of $41.79 \%$ and adsorption capacity of $0.97865 \mathrm{mg} / \mathrm{g}$.

Keywords: adsorption, allophane-like, copper $(\mathrm{Cu})$ metal ion.

\section{PENDAHULUAN}

Alofan merupakan salah satu kandungan mineral di dalam tanah liat yang bersifat amorf dan menjadi bahan yang menjanjikan secara alami tersedia di dalam tanah vulkanik. Alofan merupakan sumber daya alam yang sangat melimpah keberadaanya di alam dan dapat ditemukan dalam kandungan vulkanik. Wada and Aomine (1973) mengemukakan bahwa tanah vulkanik dapat mencapai kematangan untuk dapat digunakan dalam rentang waktu 5.000 tahun. Tanah vulkanik dapat mencapai kematangan untuk dapat digunakan dalam rentang waktu 500 sampai 1.500 tahun, tergantung faktor-faktor pembentuk tanahnya seperti tipe abu vulkanik. Tipe abu vulkanik yang berbeda-beda dapat mempengaruhi kadar kandungan alofan didalam tanah vulkanik, sehingga menyebabkan kadar alofan menjadi tidak stabil. Kadar alofan pada tanah vulkanik yang tidak stabil memiliki kadar alofan yang jauh lebih rendah dari batas atas yaitu 35-40\%. Secara alami alofan murni memiliki komposisi dan kandungan sifat yang tetap, tetapi dalam hal ini alofan alam tidak tersedia secara komersial. Alofan alam memiliki komposisi variabel rasio $\mathrm{Al} / \mathrm{Si}$ yang berbeda-beda tergantung adanya perbedaan lingkungan, dan rasio $\mathrm{Al} / \mathrm{Si}$ yang biasanya ditemukan adalah 0,2-1,7 (Pelletier et al., 2005). Rasio Al/Si dari alofan alam berubah dengan berubahnya geografis lokasi. Selain perbedaan rasio Al/Si yang berbedabeda, alofan alam biasanya mengandung banyak pengotor yang tidak diinginkan seperti partikel pasir, debu, dan ukuran partikel tanah liat yang sulit untuk dipisahkan.

Berdasarkan uraian diatas, diperlukan inovasi pembuatan alofan sintetis ataupun allophane-like yang diharapkan memiliki waktu pembentukan yang lebih singkat dan memilikiluas permukaan serta ukuran pori yang lebih besar dibandingkan dengan alofan alam. Menurut Pelletier et al. (2005), alofan sintetis dapat dibuat dengan mencampurkan larutan Tetraethyl Orthosilicate (TEOS) dan Aluminum Nitrate Nonahydrate $\left[\mathrm{Al}\left(\mathrm{NO}_{3}\right)_{3} .9 \mathrm{H}_{2} \mathrm{O}\right]$ dengan menggunakan rasio $\mathrm{Al} / \mathrm{Si} 0,5$-2,0. Semakin besar rasio mol Al/Si yang digunakan maka luas permukaan dan ukuran pori allophane-like yang dihasilkan semakin besar. Kapasitas adsorpsi akan lebih optimum pada rasio Al/Si yang lebih besar (Ohashi et al., 2002). 
Alofan memiliki kemampuan untuk menyerap logam-logam berat. Menurut Gutafsson and Karltun (1998) telah memanfaatkan alofan sebagai adsorben dalam menyerap Arsen, Sianida, Posfat, Tembaga dan Kadmium. Logam berat menjadi berbahaya karena tidak dapat didegradasi oleh tubuh, memiliki sifat toksisitas (racun) bagi makhluk hidup walaupun pada konsentrasi rendah dan dapat terakumulasi pada pada jangka waktu tertentu. Logam berat seperti tembaga merupakan contoh kontaminan yang memiliki potensi merusak sistem fisiologi manusia dan sistem biologis lainnya jika melewati tingkat toleransi. Logam tembaga $(\mathrm{Cu})$ banyak dihasilkan antara lain oleh industri pelapisan logam (plating), pencampuran logam (alloy), baja, pewarna, kabel listrik, insektisida, jaringan pipa, dan cat. Oleh karena itu pemerintah menetapkan baku mutu limbah cair industri kelas 1 kandungan logam tembaga $(\mathrm{Cu})$ kurang dari $2 \mathrm{mg} / \mathrm{L}$ dan untuk industri plating di bawah $0,6 \mathrm{mg} / \mathrm{L}$. Keberadaan ion tembaga $(\mathrm{Cu})$ dalam limbah industri biasanya disertai dengan ion logam berat lainnya. Dalam limbah industri plating, ion tembaga $(\mathrm{Cu})$ merupakan logam berat dengan konsentrasi terbesar kelima setelah logam $\mathrm{Fe}, \mathrm{Cr}, \mathrm{Sn}$, dan $\mathrm{Zn}$ kemudian diikuti oleh ion logam dengan konsentrasi yang lebih kecil, yaitu $\mathrm{Ni}, \mathrm{Mn}, \mathrm{Pb}, \mathrm{Cd}$, dan $\mathrm{Ag}$.

Pada penelitian ini dilakukan pembuatan allophane-like yang digunakan sebagai adsorben terhadap ion logam tembaga $(\mathrm{Cu})$ dan akan dipelajari karakteristik allophane-like serta efektivitasnya dalam mengadsorpsi ion logam tembaga $(\mathrm{Cu})$.

\section{METODE}

Bahan yang digunakan adalah Tetraethyl Orthosilicate (TEOS, 99\%) (Merck), Aluminum Nitrate Nonahydrate $\left[\mathrm{Al}\left(\mathrm{NO}_{3}\right)_{3} .9 \mathrm{H}_{2} \mathrm{O}, 98 \%\right]$, Akuades, $\mathrm{HNO}_{3}$ pekat (Merck), $\mathrm{CH}_{3} \mathrm{COOH}$ (Merck), $\mathrm{CH}_{3} \mathrm{COONa}$ (Merck), $\mathrm{NaOH} \mathrm{0,1} \mathrm{N}$ (Merck), larutan referensi ion logam tembaga (Cu) 1000 ppm (Merck), kertas saring (Whatman 42, Whatman 40), $\mathrm{NH}_{3}$ (Merck). Peralatan yang digunakan adalah furnace, hot plate, lumpang dan mortal, tang penjepit, statif dan klem, desikator, magnetic stirer, buret basa, pengaduk mekanik, oven, ph meter, seperangkat alat gelas, seperangkat alat X-Ray Diffraction (XRD) Shimadzu type 600, Seperangkat alat Fourier Tranform Infra Red (FT-IR) Shimadzu type FT-IR-8201 PC, Scanning Electron Microscope (SEM) FEI type Inspect S50, Surface Area Analyzer (SAA) Quantachrome type NOVA 1200, Atomic Absorption Spectroscopy (AAS) Shimadzu type AA-6650 F, Neraca analitik listrik Mettler PB 3000 Type E-182 A, Shaker Ogawa Seiki type OSK 6445. 


\section{Pembuatan Allophane-like}

Larutan Tetraethyl Orthosilicate (TEOS) dan larutan Aluminum Nitrate Nonahydrate $\left[\mathrm{Al}\left(\mathrm{NO}_{3}\right)_{3} .9 \mathrm{H}_{2} \mathrm{O}\right]$ dicampurkan pada suhu ruang untuk mendapatkan rasio volume $\mathrm{Al} / \mathrm{Si}$ masing-masing 0,$5 ; 0,75 ; 1 ; 1,25$ dan 1,5, dengan menggunakan perbandingan volume menurut Pelletier et al. (2005), dapat dilihat pada Tabel 1.

Tabel 1. Komposisi campuran untuk membuat allophane-like.

\begin{tabular}{cccc}
\hline $\begin{array}{c}\text { Rasio Volume } \\
\mathrm{Al} / \mathrm{Si}\end{array}$ & $\begin{array}{c}\text { Rasio Mol } \\
\mathrm{Al} / \mathrm{Si}\end{array}$ & $\begin{array}{c}\text { Tetraethyl } \\
\text { Orthosilicate } \\
\text { (TEOS) }\end{array}$ & $\begin{array}{c}\text { Aluminum Nitrate } \\
\text { Nonahydrate } \\
{\left[\mathrm{Al}\left(\mathrm{NO}_{3}\right)_{3} .9 \mathrm{H}_{2} \mathrm{O}\right]}\end{array}$ \\
\hline 0,5 & 0,006 & $100,00 \mathrm{~mL}$ & $50 \mathrm{~mL}$ \\
0,75 & 0,009 & $66,67 \mathrm{~mL}$ & $50 \mathrm{~mL}$ \\
1 & 0,012 & $50,00 \mathrm{~mL}$ & $50 \mathrm{~mL}$ \\
1,25 & 0,015 & $40,00 \mathrm{~mL}$ & $50 \mathrm{~mL}$ \\
1,5 & 0,018 & $33,33 \mathrm{~mL}$ & $50 \mathrm{~mL}$ \\
\hline
\end{tabular}

NaOH 0,1 N sebanyak 150 mL ditambahkam selama 3 jam (@50 mL per jam) dan dilakukan pengadukan pada campuran. Penambahan $\mathrm{NaOH}$ dilakukan dengan membuat perbandingan $(\mathrm{OH} / \mathrm{Al})$ rasio 3. Campuran larutan yang diperoleh diukur $\mathrm{pH}$ larutan dan dibuat $\mathrm{pH}$ larutan menjadi asam ( $\mathrm{pH} 3-4)$ dengan penambahan larutan buffer. Hal ini dilakukan agar terbentuk suatu campuran padatan yang stabil (Pelletier et al., 2005). Campuran didiamkan selama 24 jam agar terbentuk suatu koloid, dan kemudian dilakukan penghilangan pelarut dengan dilakukan pemanasan menggunakan oven selama 7 hari dengan suhu $100^{\circ} \mathrm{C}$. Padatan kemudian dilakukan kalsinasi selama 3 jam dengan suhu $400^{\circ} \mathrm{C}$. Allophane-like kering kemudian dilakukan analisis menggunakan FTIR, XRD, SAA, SEM, dan keasaman total menggunakan metode gravimetri.

\section{Uji Efektivitas Allophane-like}

Sebanyak 0,01 gram allophane-like ditambahkan $10 \mathrm{~mL}$ larutan model tembaga (Cu) 2 ppm dengan variasi kondisi pH larutan adalah 3, 4, 5, 6, dan 7 dengan penambahan larutan buffer. Kemudian dishaker dengan variasi waktu kontak 30, 60, 90, 120 menit. Campuran yang diperoleh kemudian disaring dengan kertas saring Whatman 42 .

Larutan yang diperoleh diukur volume sesudah adsorpsi. Kemudian diukur konsentrasi logam tembaga $(\mathrm{Cu})$ dengan AAS. Kinerja adsorben allophane-like dapat diketahui dengan membuat kurva hubungan antara massa adsorben dengan prosentase logam berat yang teradsorp. Setelah diperoleh $\mathrm{pH}$ dan waktu pada kondisi terbaik maka dilakukan adsorpsi logam tembaga $(\mathrm{Cu})$ dengan adsorben allophane-like. 


\section{HASIL DAN PEMBAHASAN}

\section{Analisis Fourier Tranform Infra Red (FTIR)}

Analisis FTIR dilakukan dengan tujuan untuk mengetahui gugus fungsional utama di dalam struktur allophane-like yang selanjutnya dibandingkan dengan hasil analisis FTIR penelitian sebelumnya oleh Pelletier et al. (2005). Hasil spektra FTIR allophane-like rasio volume $\mathrm{Al} / \mathrm{Si}$ 0,5; 0,$75 ; 1 ; 1,25$ dan 1,5 dibandingkan dengan hasil FTIR penelitian sebelumnya (Pelletier et al., 2005) ditunjukkan pada Gambar 1.

Dari Gambar 1 dapat diketahui bahwa allophane-like yang dihasilkan memiliki kemiripan serapan gugus fungsi dengan penelitian sebelumnya oleh Pelletier et al. (2005). Hasil perbandingan serapan gugus fungsi allophane-like dapat dilihat pada Tabel 2.

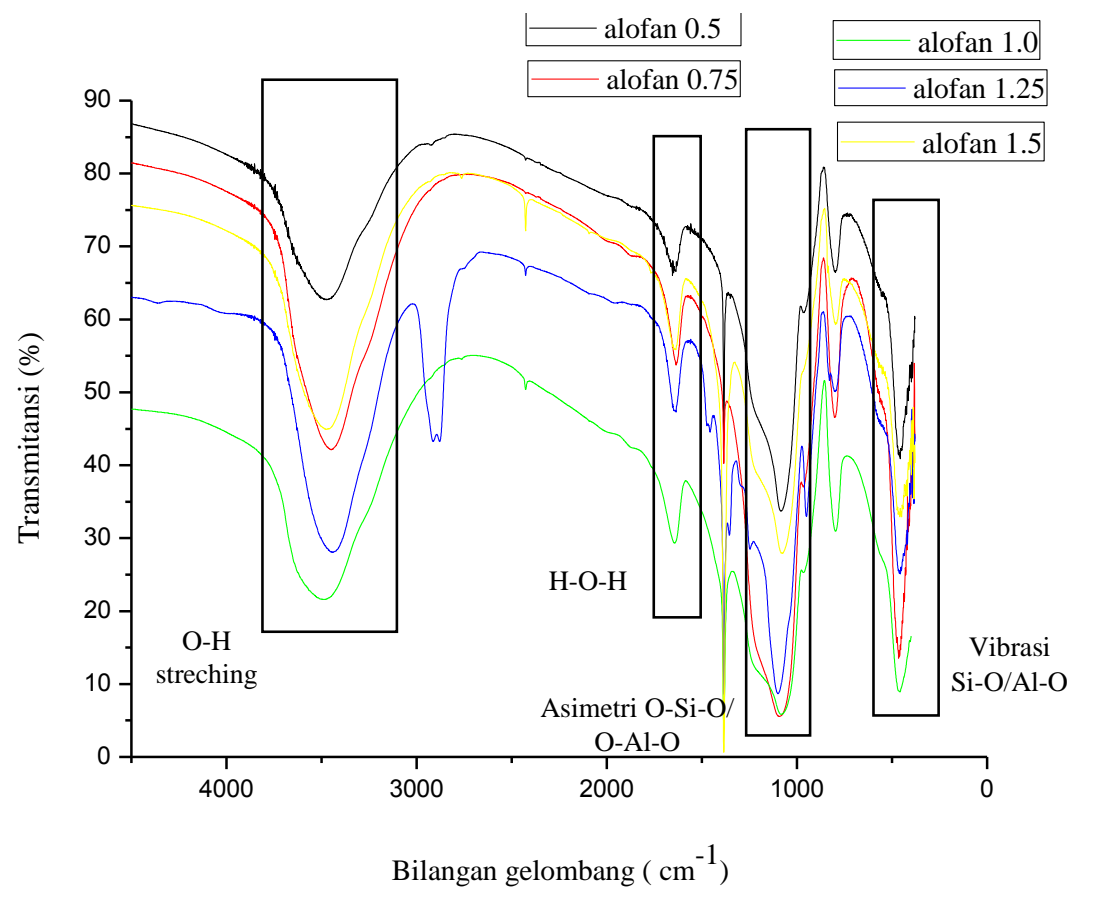

Gambar 1. Spektra FTIR allophane-like denganvariasi rasio volume Al/Si.

Dapat terlihat bahwa serapan FTIR allophane-like memiliki kemiripan serapan gugus fungsi dengan serapan FTIR dari penelitian (Pelletier et al., 2005). Pada hasil FTIR penelitian Pelletier et al. (2005) memiliki serapan gugus fungsi yaitu meliputi serapan uluran -OH , HOH, rentangan simetri O-Si-O/O-Al-O, rentangan asimetri O-Si-O/O-Al-O, dan Si-O/Al-O. Pada allophane-like dengan rasio volume Al/Si 0,5; 0,75; 1; 1,25 dan 1,5 memiliki serapan gugus fungsi yang sama yaitu serapan uluran $-\mathrm{OH}$ di daerah sekitar $3439,23-3484,56 \mathrm{~cm}^{-1}$, HOH di daerah sekitar 1631,85-1642,46 $\mathrm{cm}^{-1}$, rentangan asimetri O-Si-O/O-Al-O di daerah sekitar 949,98-1099,47 $\mathrm{cm}^{-1}$, rentangan simetri O-Si-O/O-Al-O 
di daerah sekitar 790,85-828,47 $\mathrm{cm}^{-1}$, dan Si-O/Al-O di daerah sekitar 418,57-569,03 $\mathrm{cm}^{-1}$. Pada daerah serapan sekitar $1400 \mathrm{~cm}^{-1}$ menunjukkan daerah sidik jari yang merupakan serapan gugus fungsi Si-OH/Al-OH. Berdasarkan hasil FTIR allophane-like dengan rasio volume $\mathrm{Al} / \mathrm{Si}$ 0,5; 0,75; $1 ; 1,25$ dan 1,5 didapatkan hasil yang hampir sama, dimungkinkan karena rasio yang digunakan tidak berbeda signifikan. Pada allophane-like rasio 1,25 muncul serapan baru pada daerah serapan $2800 \mathrm{~cm}^{-1}$ yang dimungkinkan merupakan serapan Si-OH. Pada allophane-like dapat dilihat ada beberapa puncak yang melebar dan tajam, hal ini dimungkinkan bertambahnya ikatan hidrogen pada serapan gugus fungsi. Allophane-like rasio Al/Si 1,5 lebih menunjukkan kemiripan dengan allophane-like hasil penelitian sebelumnya (Pelletier et al., 2005). Hal ini diperkuat dengan hasil analisis FTIR pada hasil penelitian sebelumnya Ohashi et al. (2002).

Tabel 2. Serapan Gugus Fungsi Allophane-like.

\begin{tabular}{|c|c|c|c|c|c|c|}
\hline \multirow[b]{2}{*}{ Gugus Fungsi } & \multicolumn{6}{|c|}{ Bilangan Gelombang $\left(\mathrm{cm}^{-1}\right)$} \\
\hline & $\begin{array}{c}\text { Pustaka } \\
\text { (Pelletier } \text { et } \\
\text { al., 2005) }\end{array}$ & A.S 0,5 & A.S 0,75 & A.S 1 & $\begin{array}{l}\text { A.S } \\
1,25\end{array}$ & A.S 1,5 \\
\hline Uluran $-\mathrm{OH}$ & $\begin{array}{l}3431 \\
3258 \\
\end{array}$ & 3439,23 & 3443,08 & 3484,56 & 3448,87 & 3463,34 \\
\hline $\begin{array}{c}\text { Serapan relatif } \\
\text { lemah yang } \\
\text { memperkuat adanya } \\
\text { gugus OH yaitu } \\
\text { HOH } \\
\end{array}$ & 1631 & 1640,53 & 1631,85 & 1642,46 & 1635,71 & 1632,81 \\
\hline $\begin{array}{c}\text { Rentangan } \\
\text { asimetris } \\
\text { O-Si-O dan atau } \\
\text { O-Al-O }\end{array}$ & 1071 & $\begin{array}{l}962,52 ; \\
1083,08\end{array}$ & 1039,69 & $\begin{array}{l}965,41 \\
1083,08\end{array}$ & $\begin{array}{l}949,98 \\
1099,47\end{array}$ & $\begin{array}{l}962,52 \\
1077,29\end{array}$ \\
\hline $\begin{array}{l}\text { Rentangan simetri } \\
\text { O-Si-O / O-Al-O }\end{array}$ & 785 & 798,56 & 802,42 & 797,6 & $\begin{array}{l}791,81 ; \\
828,47\end{array}$ & 790,85 \\
\hline $\begin{array}{l}\text { Vibrasi bending } \\
\text { Si-O dan atau Al-O }\end{array}$ & $\begin{array}{l}562 \\
457\end{array}$ & 556,49 & 465,83 & 459,08 & $\begin{array}{l}418,57 ; \\
461,57 ; \\
551,67\end{array}$ & $\begin{array}{l}419,54 ; \\
459,08 ; \\
473,54 ; \\
569,03\end{array}$ \\
\hline
\end{tabular}

\section{Analisis X-Ray Diffraction (XRD)}

Analisis XRD allophane-like digunakan untuk menentukan jenis mineral pada tanah. Difraktogram allophane-like ditunjukkan pada Gambar 2. 


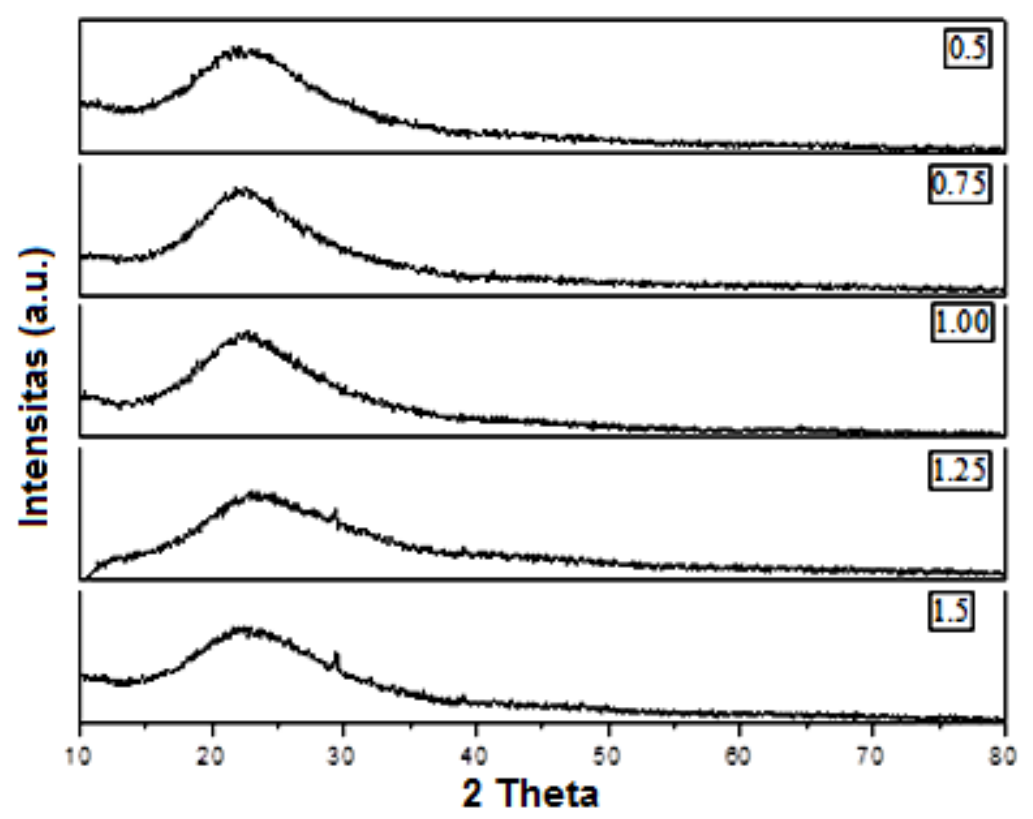

Gambar 2. Difraktogram allophane-like dengan varasi rasio volume Al/Si.

Hasil difraktogram allophane-like apabila dibandingkan dengan penelitian yang telah dilakukan sebelumnya oleh Ohashi et al. (2002), memiliki kemiripan difraktogram. Pada allophane-like tidak memiliki puncak-puncak yang spesifik dan bersifat amorf. Hal ini disebabkan karena perlakuan suhu kalsinasi terhadap sampel yang dilakukan pada suhu rendah sehingga menyebabkan allophane-like tidak memiliki keteraturan molekul, panjang dan sudut ikatan yang tidak teratur. Namun allophane-like yang dikalsinasi pada suhu $600^{\circ} \mathrm{C}$ memiliki puncak difraktogram yang spesifik, sehingga dikarenakan pada suhu yang lebih tinggi akan terbentuk keteraturan molekul, panjang dan sudut ikatan yang teratur. Hasil XRD allophane-like yang dikalsinasi pada suhu $600^{\circ} \mathrm{C}$ dapat dilihat pada Gambar 3 .

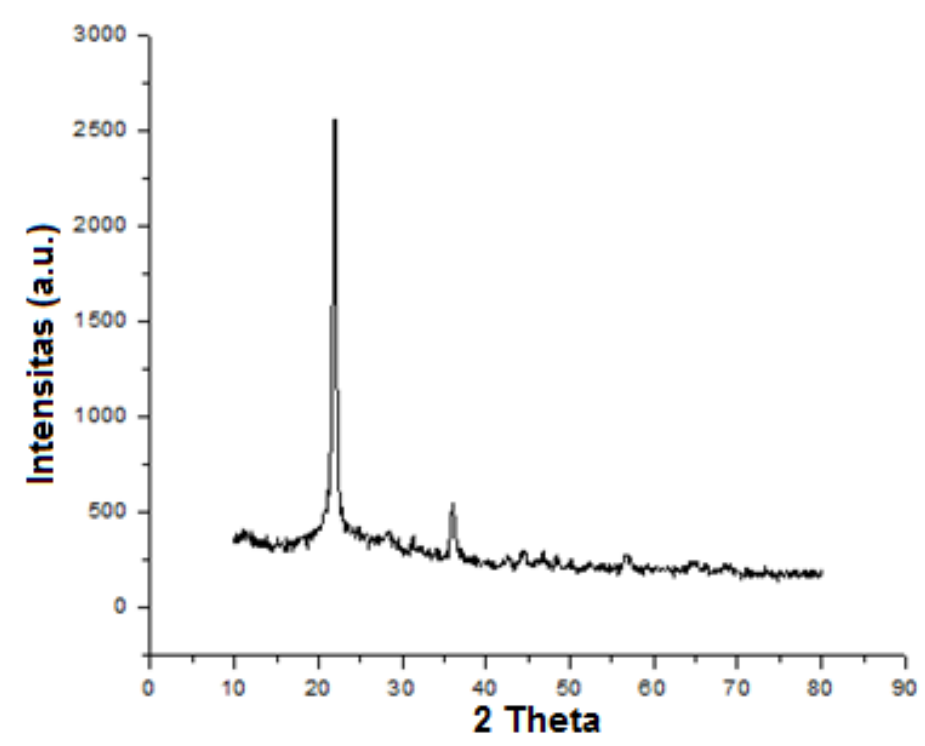

Gambar 3. Difraktogram Allophane-like kalsinasi $600^{\circ} \mathrm{C}$. 
Sampel allophane like yang diidentifikasi terlihat mempunyai struktur yang amorf, hal ini terjadi karena penataan molekul yang rendah sehingga terbentuk amorf. Selain itu kalsinasi hanya dilakukan pada suhu yang rendah yaitu suhu $400^{\circ} \mathrm{C}$. Hasil allophane like yang amorf ini sesuai dengan penelitian yang dilakukan Ohashi et al. (2002) yang ditunjukkan pada Gambar 4.

Sampel allophane like juga dilakukan kalsinasi pada suhu yang lebih tinggi yaitu suhu $600^{\circ} \mathrm{C}$ (Gambar 3). Hasil difraktogram allophane like pada suhu $600^{\circ} \mathrm{C}$ memiliki kistalinitas yang lebih tinggi dari suhu $400^{\circ} \mathrm{C}$ tetapi tidak digunakan sebagai adsorben terhadap logam $\mathrm{Cu}$ karena kapasitas adsorpsinya yang kecil. Suhu kalsinasi yang tinggi dapat menyebabkan rusaknya struktur penjerap dan menyebabkan penurunan luas permukaan sehingga media jerapannya terbatas (Hartopo, 2014).

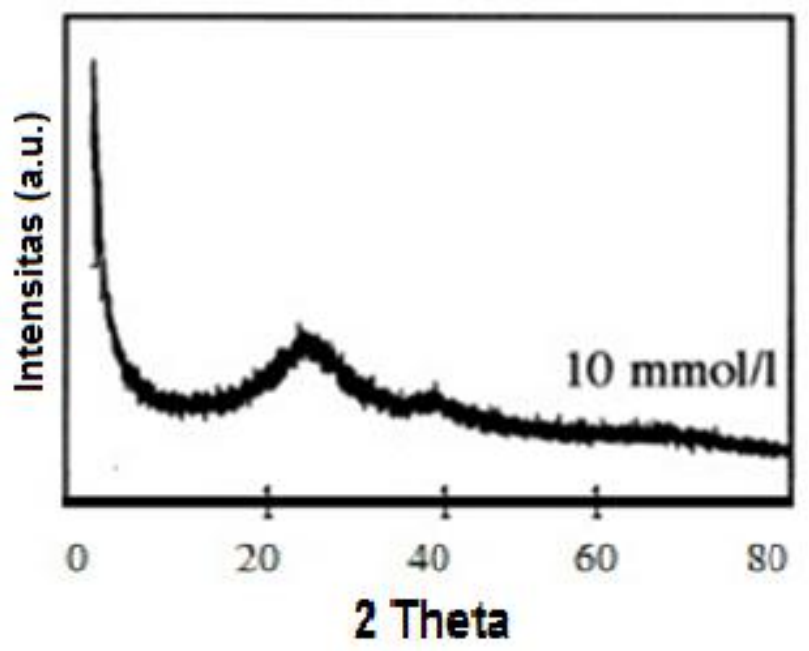

Gambar 4. XRD alofan sintetis (Ohashi et al., 2002).

\section{Analisis Scanning Electronic Microscope (SEM)}

Analisis SEM juga digunakan untuk mengetahui bentuk dan struktur dari agregat kristal, khususnya untuk mengetahui morfologi agregat allophane-like. Hal ini akan nampak jelas sekali morfologi allophane-like pada Gambar 5.

Hasil SEM menunjukkan bahwa penampang permukaan allophane-like memiliki bentuk bongkahan. Analisis SEM terutama menyangkut relatif bagian morfologi permukaan saja, tidak mampu menembus lebih dalam lagi, sehingga perlu dilakukan analisis lebih dalam untuk mengetahui komposisi permukaan sampel pada allophane-like. Hasil SEM tidak dibandingkan dengan penelitian sebelumnya, hal ini dikarenakan sejauh 
ini belum ada penelitian yang menggunakan SEM untuk menganalisa morfologi permukaan pada allophane-like.

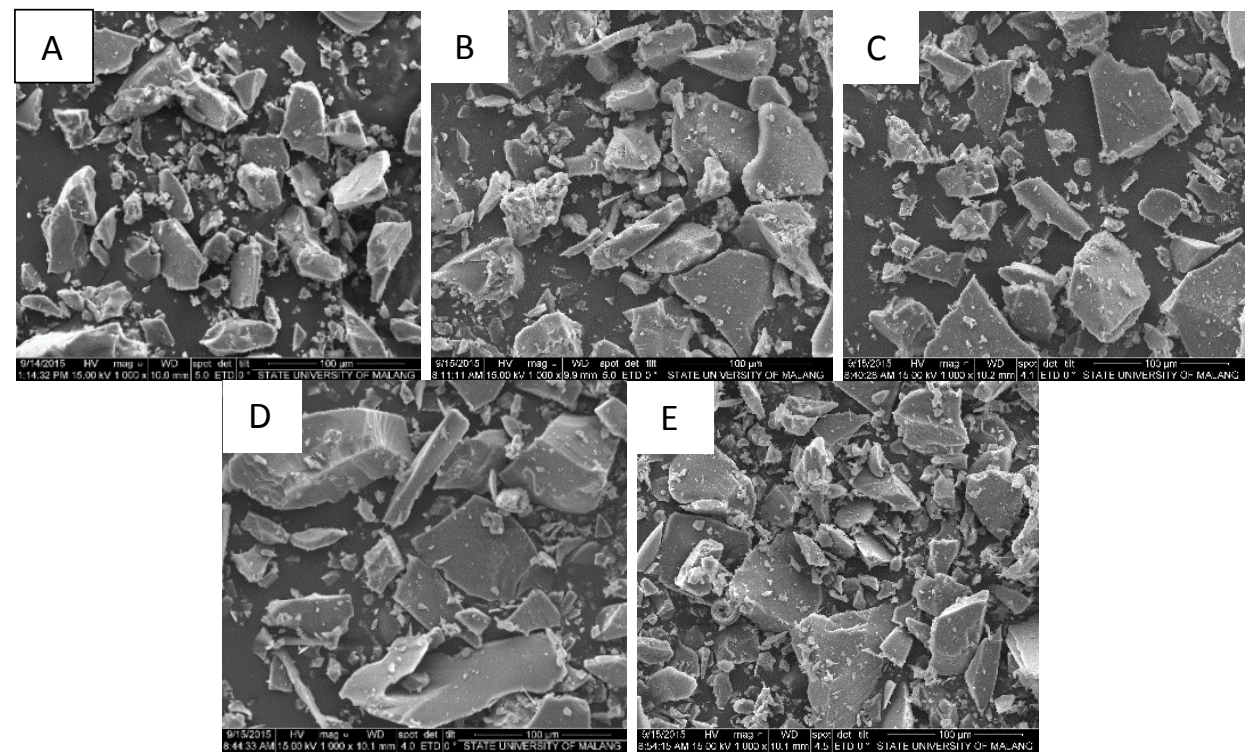

Gambar 5. Hasil analisis SEM perbesaran $100 \mu \mathrm{m}$ allophane-like rasio Al/Si (A) 0,5; (B) 0,75 ; (C) 1; (D) 1,25 dan (E) 1,5.

\section{Uji Efektivitas Allophane-like Terhadap Ion Logam Tembaga (Cu)}

Uji keefektifan allophane-like terhadap ion logam tembaga $(\mathrm{Cu})$ dilakukan untuk mengetahui rasio allophane-like yang paling optimum dalam menyerap ion logam tembaga

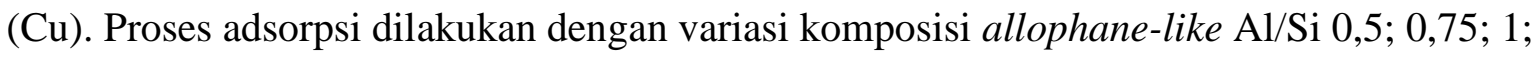
1,25 dan 1,5, pH yang digunakan yaitu 3; 4; 5; 6 dan 7 menggunakan metode batch. Analisis adsorpsi logam dilakukan berdasarkan konsentrasi yang terserap dan waktu kontak. $\mathrm{pH}$ dan waktu kontak merupakan beberapa faktor yang mempengaruhi proses adsorpsi. Variasi terhadap waktu kontak dimaksudkan untuk mengetahui waktu kontak terbaik saat adsorpsi kation oleh alofan. Variasi waktu yang digunakan adalah 30, 60, 90, dan 120 menit.

Pada proses adsorpsi digunakan sampai pH 7 karena dari analisis yang dilakukan dengan mengukur $\mathrm{pH}$ larutan ion logam tembaga $(\mathrm{Cu})$ didapatkan bahwa logam tembaga $(\mathrm{Cu})$ mengendap pada $\mathrm{pH}$ 7. Penggunaan $\mathrm{pH}$ lebih dari 6,28 dapat menyebabkan terjadinya pengendapan logam tembaga $(\mathrm{Cu})$ menjadi $\mathrm{Cu}(\mathrm{OH})_{2}$ yang dapat mempengaruhi berlangsungnya proses adsorpsi (Sajidu et al., 2006).

Perbandingan rasio $\mathrm{Al} / \mathrm{Si}$ dapat mempengaruhi kapasitas adsorpsi, dimana semakin tinggi rasio $\mathrm{Al} / \mathrm{Si}$ maka kapasitas adsorpsi akan naik. Nilai $\mathrm{pH}$ dan waktu kontak sangat berpengaruh pada proses adsorpsi. Kenaikan $\mathrm{pH}$ dapat menyebabkan proses adsorpsi 
meningkat, tetapi akan kembali menurun jika melewati titik optimum yang dicapai. Pada $\mathrm{pH}$ rendah (asam) jumlah proton $\mathrm{H}^{+}$meningkat sehingga mengakibatkan peluang terjadinya pengikatan logam oleh adsorben relatif kecil (Taty et al., 2003). Pada pH netral ion-ion logam dapat mengalami reaksi hidrolisis dalam larutan, sehingga menjadi tidak stabil dalam bentuk ion logam semula dan kemampuan adsorpsinya mengalami penurunan. Pada $\mathrm{pH}$ basa jumlah proton $\mathrm{H}^{+}$kecil sehingga mengakibatkan peluang terjadinya pengikatan logam oleh adsorben relatif besar yang akan dapat membentuk endapan hidroksida dan mengakibatkan kemampuan adsorpsinya menurun (Cordero et al., 2004).

Waktu kontak antara adsorben dengan ion logam yang lebih lama memungkinkan terjadinya peningkatan penyerapan ion logam namun jika terlalu lama dapat menurunkan tingkat penyerapan. Hal ini disebabkan semakin lama waktu kontak dapat mengakibatkan desorpsi, yaitu proses pelepasan kembali ion atau molekul yang telah berikatan dengan gugus aktif yang ada.

Berdasarkan Gambar 6 (A-E) dapat terlihat bahwa kondisi adsorpsi untuk tiap rasio terdapat pada pH 6 dengan waktu kontak 120 menit. Kapasitas adsorpsi yang terjadi terdapat pada rasio Al/Si 1,5 pH 6 waktu kontak 120 menit sebesar 0,97865 mg/g dengan persentase penyerapan terhadap ion logam $\mathrm{Cu}^{2+}$ sebesar 41,89\%.

Pada diagram uji kinerja allophane-like, dapat dilihat bahwa semakin tinggi $\mathrm{pH}$, rata-rata kapasitas adsorpsi mengalami kenaikan hingga kondisi optimum dan setelah itu akan turun kembali. Pada masing-masing rasio $\mathrm{Al} / \mathrm{Si} \mathrm{pH}$ optimum adsorpsi ion logam berat $\mathrm{Cu}$ pada $\mathrm{pH}$ 6. Pada $\mathrm{pH}$ rendah $(<4)$ akan terjadi protonasi yang mengakibatkan terbentuknya $\mathrm{H}_{3} \mathrm{O}^{+}$. Hal ini akan menyebabkan kompetisi antara ion $\mathrm{Cu}^{2+}$ dengan $\mathrm{H}_{3} \mathrm{O}^{+}$ untuk berikatan dengan situs negatif adorben sehingga penyerapan adsorbat akan terganggu. Kapasitas adsorpsi yang dihasilkan memiliki nilai yang lebih kecil. Pada $\mathrm{pH}$ yang tinggi, akan terbentuk endapan $\mathrm{Cu}(\mathrm{OH})_{2}$ sehingga daya serap adsorben akan berkurang sehingga nilai kapasitas adsorpsi akan turun.

Pada penelitian ini, pada masing-masing rasio $\mathrm{Al} / \mathrm{Si}$ memiliki waktu kontak optimum pada 120 menit. Waktu kontak merupakan waktu yang diperlukan adsorben untuk menyerap ion logam berat pada adsorbat. Ion logam $\mathrm{Cu}^{2+}$ akan menempel pada permukaan adsorben sampai waktu kontak optimum. Ketika waktu kontaknya telah cukup atau lewat jenuh maka ion logam $\mathrm{Cu}^{2+}$ tidak dapat diterima lagi oleh permukaan adsorben dan akan dilepas kembali ke dalam larutan. Hal ini akan mengakibatkan nilai kapasitas adsorpsi berkurang atau menurun. 

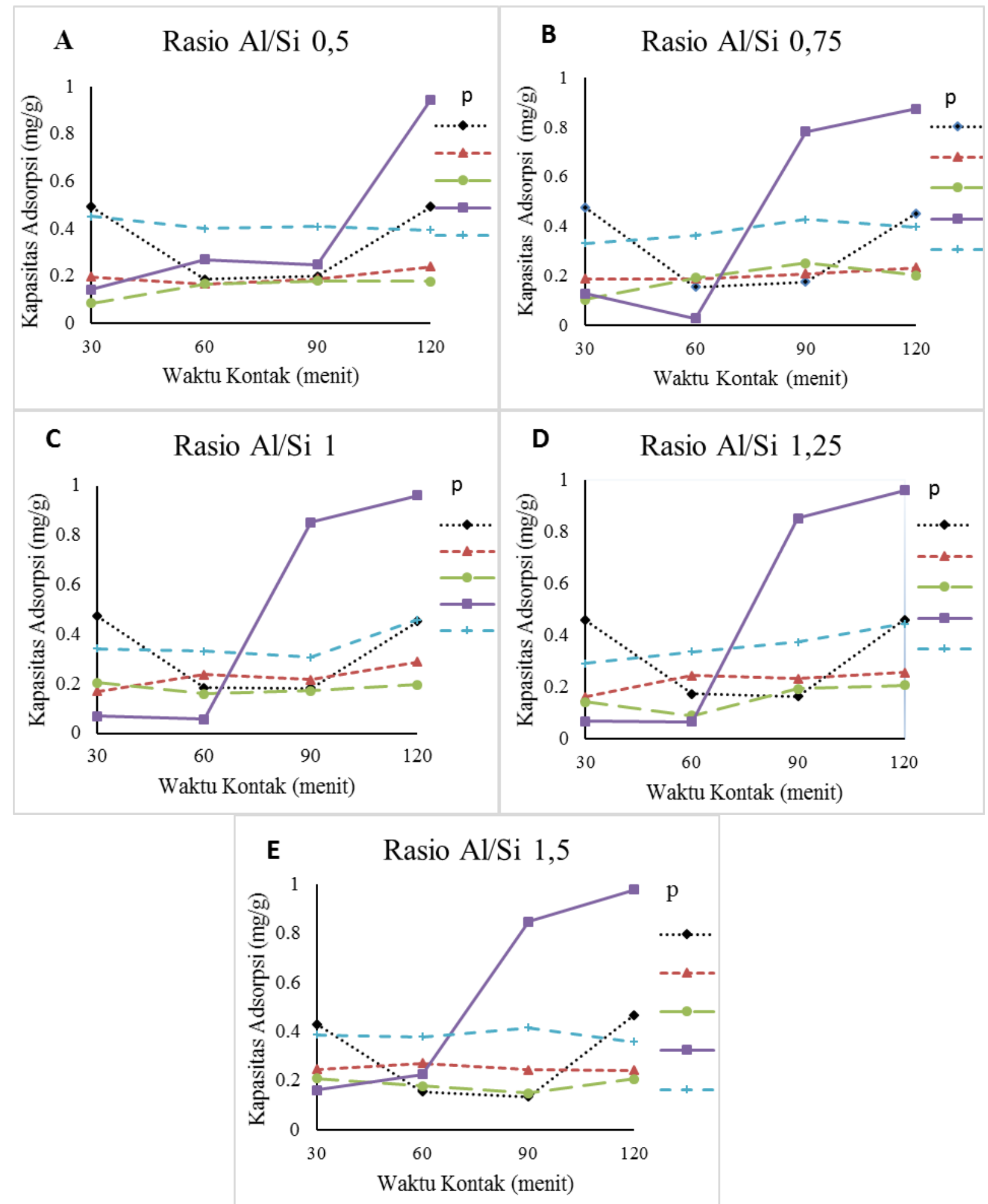

Gambar 6. Grafik adsorpsi allophane-like rasio $\mathrm{Al} / \mathrm{Si}$ (A) 0,5; (B) 0,75; (C) 1,00; (D) 1,25 dan (E) 1,50. 
Tabel 3. Perbandingan Kapasitas Adsorpsi

\begin{tabular}{clr}
\hline No. & Sampel & Kapasitas Adsorpsi (mg/g) \\
\hline 1. & Allophane-like & 0,97865 \\
2. & Alofan G. Arjuna TA ${ }^{(1)}$ & 1,235 \\
3. & Alofan G. Arjuna Aktivasi NaOH 3 N 5 jam \\
4. & Alofan G. Papandayan TA \\
5. & Alofan G. Papandayan Aktivasi NaOH 3 N 2 & 0,1785 \\
& jam \\
6. & Alofan G. Arjuna TA & 0,044 \\
7. & Alofan G. Arjuna Aktivasi NaOH 3 N 1 jam \\
8. & Alofan G. Wilis TA \\
9. & Alofan G. Wilis Aktivasi NaOH 3 N 2 jam \\
& \\
\hline
\end{tabular}

Keterangan :

(1) Sulistyarini (2011)

$* \mathrm{TA}=$ Tanpa Aktivasi

(2) Pranoto et al. (2013)

Hasil perbandingan kapasitas adsorpsi allophane-like dengan alofan alam berbagai referensi menunjukkan bahwa allophane-like memiliki kemampuan adsorpsi yang lebih tinggi dibandingakan dengan alofan alam. Namun, allophane-like memiliki kapasitas adsorpsi yang lebih rendah apabila dibandingkan dengan alofan alam Gunung Arjuna yang memiliki kapasitas adsorpsi $1,235 \mathrm{mg} / \mathrm{g}$.

\section{Karakterisasi Adsorben}

Karakterisasi adsorben bertujuan untuk mengetahui luas permukaan pada allophane-like dengan dibandingkan dengan alofan alam.

\section{a. Analisis Luas Permukaan}

Luas permukaan merupakan faktor penting dalam proses adsorpsi karena semakin besar luas permukaan maka semakin besar kemampuan adsorpsinya. Luas permukaan dinyatakan dalam jumlah total luas permukaan allophane-like yang berbentuk serbuk dalam setiap massa allophane-like. Pada pengukuran luas permukaan digunakan alat SAA. Hasil pengukuran luas permukaan allophane-like dibandingkan dengan data luas permukaan dari penelitian sebelumnya yang dilakukan oleh Pelletier et al. (2005), dapat dilihat pada Tabel 4.

Tabel 4. Data analisis luas permukaan adsorben.

\begin{tabular}{rlc}
\hline No. & Adsorben & Luas permukaan $\left(\mathrm{m}^{2} / \mathrm{g}\right)$ \\
\hline 1. & Allophane-like & 201,558 \\
2. & Allophane-like & 434,000 \\
\hline
\end{tabular}

Keterangan : ${ }^{(1)}$ Pelletier et al. (2005) 
Pada Tabel 4 menunjukkan bahwa luas permukaan allophane-like (Pelletier et al., 2005) lebih besar dibandingkan dengan allophane-like yang dihasilkan. Hal ini dikarenakan allophane-like yang dihasilkan tidak dilakukan proses dialisis. Sehingga kemungkinan masih terdapat garam $\mathrm{NaNO}_{3}$ didalam allophane-like, yang dapat menutupi permukaan allophane-like.

\section{b. Analisis Keasaman}

Analisis keasaman dilakukan dengan menggunakan metode adsorpsi basa amonia, yaitu melalui pengukuran jumlah basa amonia yang bereaksi dengan gugus asam padatan, dimana jumlah basa amonia yang diadsorpsi oleh permukaan padatan adalah sebanding dengan jumlah asam pada permukaan padatan yang menyerap basa tersebut. Keasaman adalah jumlah milimol asam per satuan berat adsorben. Uji keasaman hanya untuk menunjukkan adanya situs asam pada permukaan allophane-like. Hasil pengukuran keasaman pada allophane-like yaitu 2,728 $\pm 0,114 \mathrm{mmol} / \mathrm{g}$. Hal ini menunjukkan bahwa data yang didapatkan nilai keasaman allophane-like dapat menunjukkan situs aktif yang dimiliki oleh allophane-like untuk mengadsorp ion logam tembaga $(\mathrm{Cu})$.

\section{c. Analisis FTIR Adsorben Setelah Adsorpsi}

Karakterisasi FTIR adsorben setelah adsorpsi dilakukan untuk mengetahui ikatan yang terjadi antara allophane-like rasio $\mathrm{Al} / \mathrm{Si}$ 1,5, allophane-like rasio $\mathrm{Al} / \mathrm{Si}$ 1,5 dengan ion logam tembaga $(\mathrm{Cu})$ dilihat dari perbedaan spektra FTIR sebelum dan sesudah adsorpsi yang ditunjukkan pada Gambar 7. Gambar 7 (a) menunjukkan karakterisasi serapan FTIR allophane-like sebelum adsorpsi ion logam tembaga $(\mathrm{Cu})$ dan Gambar 7 (b) menunjukkan allophane-like setelah adsorpsi ion logam tembaga $(\mathrm{Cu})$. Dari kedua spektra tersebut terlihat perbedaan pada daerah serapan 3463,34 bergeser ke bilangan gelombang yang lebih kecil yaitu 3439,23, hal ini dimungkin karena adanya interaksi dengan ikatan hidrogen. Perbedaan serapan juga terjadi pada daerah $1383,98 \mathrm{~cm}^{-1}$, hal ini mengidentifikasikan adanya interaksi gugus fungsi $\mathrm{Si}-\mathrm{OH} / \mathrm{Al}-\mathrm{OH}$ yang berikatan dengan ion logam tembaga $(\mathrm{Cu})$ menjadi $\mathrm{Si}-\mathrm{O}-\mathrm{Cu} / \mathrm{Al}-\mathrm{O}-\mathrm{Cu}$. Adanya interaksi dengan logam tembaga $(\mathrm{Cu})$ mengakibatkan bergesernya serapan yang terjadi setelah adsorpsi, sehingga serapan gugus fungsi bergeser bilangan gelombangnya. Pada serapan 1077,29 $\mathrm{cm}^{-1}$ bergeser ke bilangan gelombangyang lebih besar yaitu pada daerah $1081,15 \mathrm{~cm}^{-1}$, hal ini mengidentifikasikan terjadi ikatan pada rentangan asimetris $\mathrm{O}-\mathrm{Si}-\mathrm{O}$ atau O-Al-O dengan ion logam tembaga $(\mathrm{Cu})$ atau adanya interaksi dengan ikatan hidrogen. Kemungkinan reaksi yang terjadi ketika proses adsorpsi dapat ditunjukkan oleh Gambar 8 . 


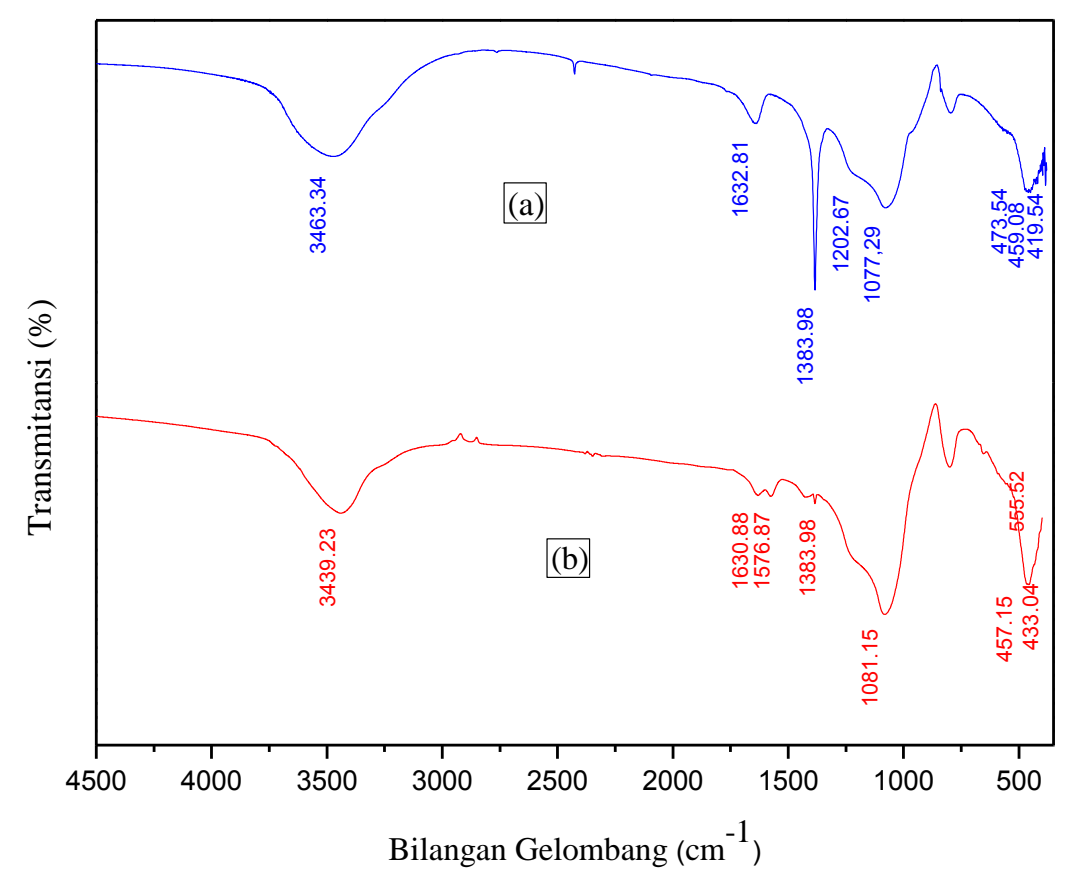

Gambar 7. (a) Allophane-like rasio Al/Si 1,5 sebelum adsorpsi (b) Allophane-like rasio $\mathrm{Al} / \mathrm{Si} 1,5$ setelah adsropsi ion logam tembaga $(\mathrm{Cu})$.

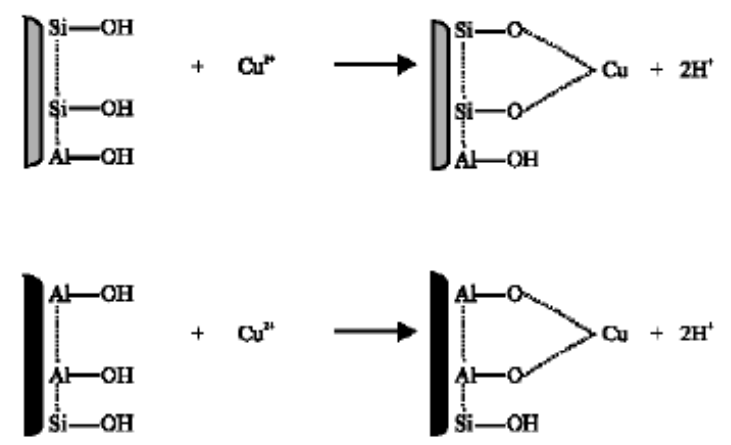

Gambar 8. Kemungkinan reaksi yang terjadi pada proses adsorpsi.

\section{Penentuan Persamaan Isoterm Adsorpsi}

Isoterm adsorpsi digunakan untuk menentukan jenis adsorpsi yang terjadi sesuai dengan persamaan Langmuir atau persamaan Freundlich. Penentuan isoterm tersebut didasarkan atas harga $\mathrm{R}^{2}$ dari masing - masing adsorben, semakin harga $\mathrm{R}^{2}$ mendekati 1 maka tingkat kesalahan yang terjadi semakin sedikit. Penentuan ini dilakukan dengan melakukan adsorpsi ion logam tembaga $(\mathrm{Cu})$ dengan rasio $\mathrm{Al} / \mathrm{Si} 1,5 \mathrm{pH} 6$ waktu kontak 120 menit. Variasi konsentrasi larutan ion logam tembaga $(\mathrm{Cu})$ yang digunakan yaitu 2, 4, 6, 8, $10 \mathrm{ppm}$. 
Setelah dilakukan uji secara regresi linier sederhana dengan menggunakan persamaan Langmuir dan Freundlich. Persamaan isoterm Langmuir ditentukan dengan menggunakan persamaan isoterm Langmuir (1) dan dibuat kurva Ce vs Ce/Qe

$$
\frac{C_{e}}{Q_{e}}=\frac{1}{K Q_{\max }}+\frac{C_{e}}{Q \max }
$$

Selanjutnya, persamaan isoterm Freundlich ditentukan dengan menggunakan persamaan isoterm Freundlich (2) lalu dibuat kurva Log Ce vs Log Qe.

$$
\log \mathrm{Qe}=\log \mathrm{K}+\frac{1}{n} \log \mathrm{Ce}
$$

Isoterm Langmuir menunjukkan bahwa proses adsorpsi terjadi secara kimia yaitu situs aktif adsorben akan berinteraksi dengan gugus logam tembaga $(\mathrm{Cu})$ pada larutan dengan membentuk suatu senyawa. Proses adsorpsi menurut Langmuir menunjukkan bahwa interaksi antara logam tembaga $(\mathrm{Cu})$ dengan permukaan adsorben pada pembentukan lapisan tunggal (monolayer).

Isoterm Freundlich merupakan isoterm yang menggambarkan proses adsorpsi secara fisika. Adsorpsi fisika terjadi bila gaya intermolekular lebih besar dari gaya tarik antar molekul. Interaksi terjadi dengan cara logam berat memasuki pori-pori adsorben tanpa membentuk ikatan atau berinteraksi dengan energi ikat yang lemah yaitu melalui ikatan van der waals. Gaya tarik menarik yang lemah tersebut menyebabkan adsorbat dapat bergerak dari satu bagian permukaan ke bagian permukaan lain dari adsorben. Ikatan van der waals yang terjadi antara adsorben dengan logam tembaga $(\mathrm{Cu})$ yaitu karena struktur adsorben memiliki gugus $\mathrm{SiO}_{4}$ sehingga permukaannya negatif akan mengikat ion logam tembaga $(\mathrm{Cu})$. Sesuai dengan hasil perhitungan isoterm yang menunjukan adanya adsorpsi fisika bahwa pada proses adsorpsi tidak terjadi transfer elektron sehingga hanya terjadi ikatan yang lemah.

Kurva isoterm Langmuir dan Freundlich untuk ion logam tembaga $(\mathrm{Cu})$ dapat dilihat pada Gambar 9 (A-B). 

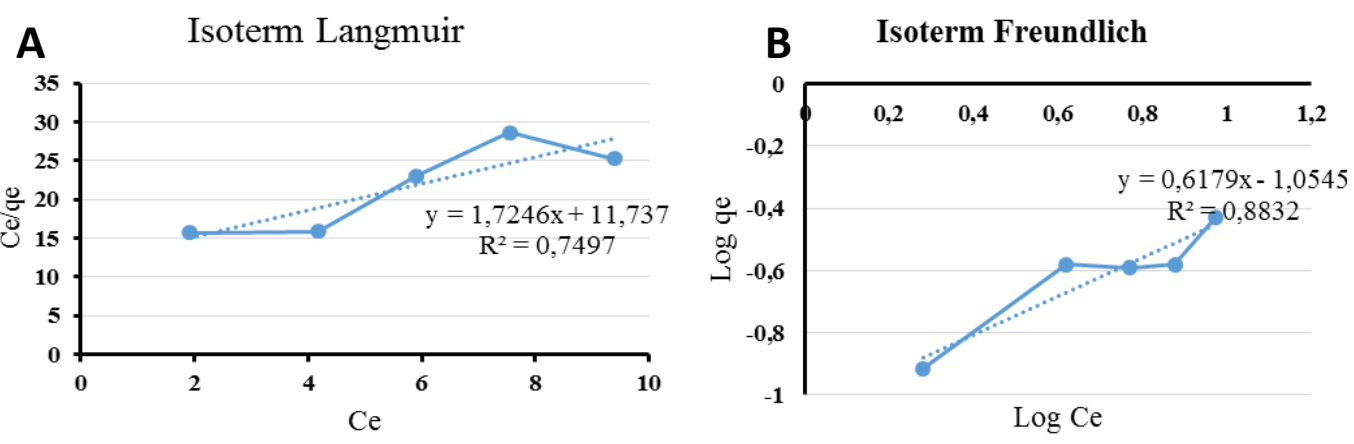

Gambar 9. Kurva isoterm (A) Langmuir dan (B) Freundlich untuk ion logam tembaga $(\mathrm{Cu})$.

Berdasarkan data harga $\mathrm{R}^{2}$ dari isoterm Langmuir dan isoterm Freundlich diatas, dapat diketahui bahwa harga $\mathrm{R}^{2}$ dari isoterm Langmuir sebesar 0,7497 dengan persamaan garis $\mathrm{y}=1,7246 \mathrm{x}+11,737$, sedangkan isoterm Freundlich sebesar 0,8832 dengan persamaan garis $y=0,6179 x-1,0545$. Nilai $R^{2}$ yang didapatkan belum mendekati 1 , hal ini dikarenakan pada proses adsorpsi belum terjadi kapasitas adsorpsi yang konstan, sehingga waktu yang dibutuhkan untuk mencapai waktu yang konstan lebih dari waktu 120 dan menyebabkan nilai $\mathrm{R}^{2}$ yg didapatkan belum linier. Namun dilihat dari nilai $\mathrm{R}^{2}$ keduanya, nilai $\mathrm{R}^{2}$ dari persamaan Freundlich lebih tinggi daripada nilai $\mathrm{R}^{2}$ dari persamaan Langmuir meskipun keduanya belum mendekati nilai 1. Sehingga dapat disimpulkan bahwa penelitian ini mengikuti 2 isoterm, yaitu isoterm Langmuir dan isoterm Freundlich. Namun yang lebih dominan pada penelitian ini adalah isoterm Freundlich.

\section{KESIMPULAN}

Allophane-like dengan penambahan kalsinasi memiliki luas permukaan sebesar 201,558 $\mathrm{m}^{2} / \mathrm{g}$. Berdasarkan data XRD, allophane-like memiliki sifat amorf. Hasil analisis SEM menunjukkan bahwa allophane-like memiliki struktur berupa bongkahan/serpihan. Allophane-like memiliki efektifitas adsorpsi ion logam tembaga $(\mathrm{Cu})$ pada rasio $\mathrm{Al} / \mathrm{Si}$ 1,5 dengan waktu kontak 120 menit pada pH 6 sebesar 0,97865 mg/g dengan persentase penyerapan terhadap ion logam tembaga $(\mathrm{Cu})$ sebesar $41,89 \%$.

\section{DAFTAR PUSTAKA}

Cordero, B., Loidero, P., Herrero, R., and Vicente, 2004. Biosorption of Cadmium by Fucus Spiralis, Journal Environ Chem I 180-187

Gutafsson, J.P., Karltun, E., and Bhattacharya, P., 1998, Allophane and Imogolite in Swedish Soil, In Research Report TRITA-AMI 3046 Division of Land and Water 
Resource, Department of Civil and Environmental Engineering, Royal Institut of Technology (KTH), Stockholm, Sweden.

Hartopo, 2014, Kajian Efektivitas Campuran Lempung Bekonang dan Andisol Gunung Lawu sebagai Penjerap Logam Berat Mangan (Mn) untuk Peningkatan Kualitas Air, Thesis, Ilmu Lingkungan Universitas Sebelas Maret.

Ohashi, F., Wada, K., Suzuki, M., Maeda, M., and Tomura S., 2002. Synthetic allophane from highconcentration solutions: nanoengineering of the porous solid. Journal Clay Minerals 37, 451-456.

Pelletier, E.M., Sandrine, B., Manuel, P., Angelina, R., Jaafar, G., Bruno, L., and Laurent, M., 2005 Synthetic allophane-like particles: textural properties. Colloids and Surfaces A: Physicochemical and Engineering Aspects 255, 1-10.

Pranoto P., Suranto., Sugiyarto and Ashadi., 2013, Javanese Volcanic Allophane Adsorbent as Heavy Metal Adsorber to Improve the Quality of Drinking Water in Surakarta. Journal of Environment and Earth Science, 3, 48-56.

Sajidu, S.M.I., Persson, I., Masamba, W.RL., Henry, E.M.T., and Kayambazinthu, D., 2006. Removal of $\mathrm{Cd}^{2+}, \mathrm{Cr}^{3+}, \mathrm{Cu}^{2+}, \mathrm{Hg}^{2+}, \mathrm{Pb}^{2+}$ and $\mathrm{Zn}^{2+}$ cations and $\mathrm{AsO}_{4}{ }^{3-}$ anions from aqueous solutions by mixed clay from Tundulu in Malawi and characterisation of the clay. Water SA 32, 519-526.

Sulistyarini, A., 2011. Identifikasi, Karakterisasi, dan Aktivasi Alofan Gunung Arjuna Jawa Timur Sebagai Penjerap Logam Tembaga $(\mathrm{Cu})$. Skripsi. Universitas Sebelas Maret Surakarta.

Taty, C.V.C,, H, Fauduet., C, Porte and., A., and Delacrix., 2003. Removal of Cd (II) and $\mathrm{Pb}$ (II) Ions from Aqueous Solution by Adsorption onto Swadust of Pinus sylvestris. Journal Hazard Mater 121-142.

Wada, K., and Aomine, S., 1973. Soil Development of Volcanic Material During The Quaternary. Journal Soil Science 116, 170-177. 